\title{
A WHITE-EYED SPOTTED TOWHEE OBSERVED IN NORTHWESTERN NEBRASKA
}

\author{
RICK WRIGHT, 128 Evans Road, Bloomfield, New Jersey 07003; rwright@aba.org
}

Towhees visually — and in rare cases vocally_resembling the Eastern Towhee (Pipilo erythrophthalmus) have been reported at least eight times this century in the Nebraska Panhandle (Silcock and Jorgensen 2018), far to the west of that taxon's expected range. As a result of the resplitting of the Eastern Towhee and Spotted Towhee (P. maculatus) (AOU 1995), observers have begun to once again pay close attention to the appearance and vocalizations of the region's towhees, a practice that had declined following the species' earlier taxonomic lumping (AOU 1954).

On 20 and 21 May 2018, I observed a Spotted Towhee (presumptively P. m. arcticus, which breeds in the area) with white irides in the campground at the GilbertBaker Wildlife Area $\left(42^{\circ} 46.02^{\prime} \mathrm{N}, 103^{\circ} 55.67^{\prime} \mathrm{W}\right)$ in the extreme northwest of the Nebraska Panhandle, $10 \mathrm{~km}$ north of Harrison, Sioux County. I photographed the bird on the first date (Figure 1). The deep saturated black of the head indicated that this individual was a male; the browner primaries were presumably retained juvenile feathers, contrasting with the rest of the formative plumage, identifying this as an individual in its second calendar year. When I returned on the second date, the towhee was accompanied by a female Spotted Towhee of unknown age; her plumage and soft-part colors were unremarkable. Silent the day before, on this occasion the male sang several times, a series of loud ticking notes followed by a lower-pitched, buzzy trill indistinguishable to my ear from the vocalizations of other nearby Spotted Towhees.

The eye color of juvenile male Spotted Towhees was described by Davis (1957) as at first grayish brown and by Oberholser (1974) as light brown, the iris color gradu-

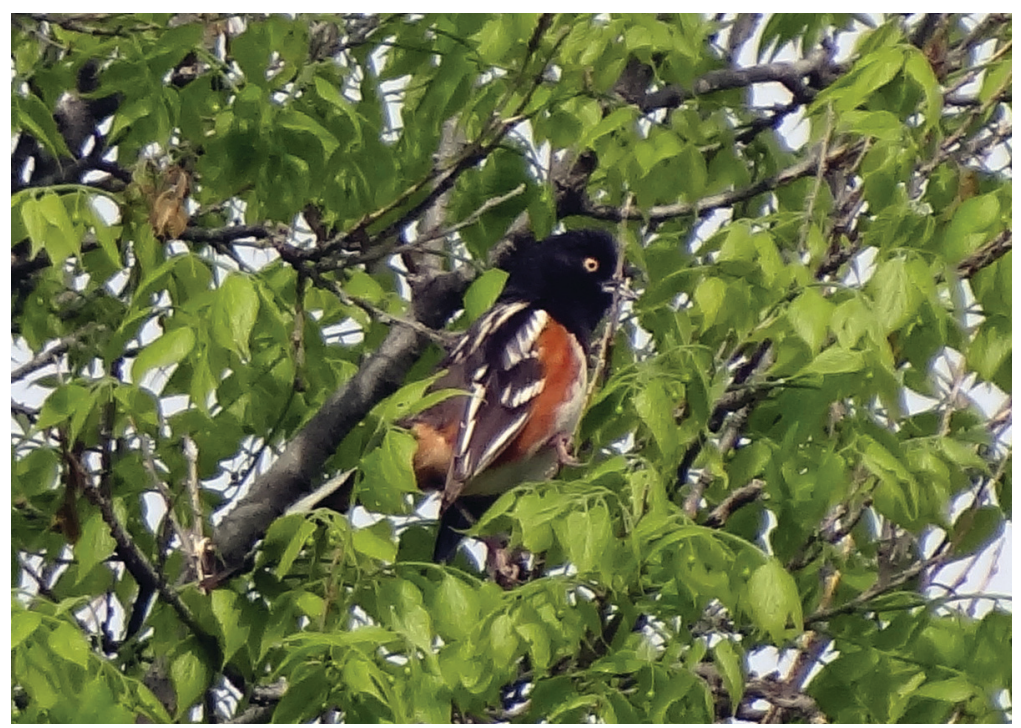

Figure 1. Spotted Towhee with white irides at the Gilbert-Baker Wildlife Area, Sioux County, Nebraska, 20 May 2018.

Photo by Rick Wright 


\section{NOTES}

ally intensifying to pale or dull orange and in most birds to an intense red by the end of May (Davis 1957). To my knowledge, based on review of the relevant literature and the online databases of several large museum collections, my observation is the first report of white eyes in the Spotted Towhee, though Oberholser (1974:896) recorded colors ranging from "carmine" to "light brownish yellow" in adult males of P. $m$. arcticus from Texas. As Davis (1957:200) noted, the true incidence of aberrant iris coloration in this species is obscured by the lack of eye-color data for "the great majority of museum specimens" of the Spotted Towhee. Though it is probably impossible to identify the mechanism responsible for the Nebraska individual's white irides, it can be assumed that a mutation resulted in a change in the pigments deposited in the layer of the iris, the stroma, responsible for color. In bird eyes, white as well as other colors is due to pigments within the cells of the stroma (Sweijd and Craig 1991). This mutation appears to have affected only iris color, leaving the colors of the other soft parts unchanged.

It is worth noting that pale yellow eyes prevail in the southernmost subspecies of the Eastern Towhee, $P$. e. alleni. In two further subspecies, $P$. e. canaster and $P$. e. rileyi, both breeding in the southeastern U.S., the iris color varies from red, as in the more northerly nominate race, to "straw color," only slightly darker than in alleni (Dickinson 1952:279). The occurrence of white irides in an adult Spotted Towhee, far from the range of any pale-eyed population of the Eastern Towhee, suggests that eye color in rufous-sided towhees is more plastic than hitherto believed, and that white-eyed birds should be looked for throughout the ranges of both the Eastern and Spotted towhees.

\section{LITERATURE CITED}

American Ornithologists' Union (AOU). 1954. Twenty-ninth supplement to the American Ornithologists' Union Check-list of North American Birds. Auk 71:310-312; doi 10.2307/4081674.

AOU. 1995. Fortieth supplement to the American Ornithologists' Union Check-list of North American Birds. Auk 112:819-830.

Davis, J. 1957. Determination of age in the Spotted Towhee. Condor 59:195-202; doi $10.2307 / 1364724$.

Dickinson, J. C. 1952. Geographic variation in the Red-eyed Towhee of the eastern United States. Bull. Mus. Comp. Zool. 107:271-352.

Oberholser, H. C. 1974. The Bird Life of Texas. Univ. Texas Press, Austin.

Silcock, W. R., and Jorgensen, J. G. 2018. Eastern Towhee (Pipilo erythrophthalmus), in Birds of Nebraska-Online; www.BirdsofNebraska.org, visited 7 Dec 2018.

Sweijd, N., and Craig, A. J. F. K. 1991. Histological basis of age-related change in iris color in the African Pied Starling (Spreo bicolor). Auk 108:53-59; doi 10.1093/auk/108.1.53.. 